\title{
Executive Accountability in Parliamentary Democracies: A Comparative Overview: Britain, Germany, India and Ethiopia
}

\author{
Andualem Nega Ferede \\ School of Law, Hawassa University, Hawassa City, Ethiopia \\ Email: andualemnega@yahoo.com
}

How to cite this paper: Ferede, A. N. (2018). Executive Accountability in Parliamentary Democracies: A Comparative Overview: Britain, Germany, India and Ethiopia. Beijing Law Review, 9, 583-599. https://doi.org/10.4236/blr.2018.95034

Received: July 6, 2018

Accepted: October 21, 2018

Published: October 25, 2018

Copyright $\odot 2018$ by author and Scientific Research Publishing Inc. This work is licensed under the Creative Commons Attribution International License (CC BY 4.0).

http://creativecommons.org/licenses/by/4.0/

\section{(c) (7) Open Access}

\begin{abstract}
Democracies especially parliamentary democracies must ensure that public bodies and officials are performing to their full potential, providing value for money in the provision of public services, building confidence in the society, and being responsive to the community they are meant to be serving. The objective of the article is to explain and compare on the functioning parliamentary democracies, Britain, Germany, India and Ethiopia, to give an insight how the parliaments account the executive to bring better governance. Britain is the oldest parliamentary democracy; Germany with handy parliamentary democracy and functional federalism and India is the largest parliamentary democracy. These countries have much experience Ethiopia has to learn. Thus the article considered the institutional structure of accountability; parliamentary control strategies without jeopardizing the concept of separation of powers in a these four countries. The parliamentary system is portrayed under FDRE Constitution and other legislations. The article explored these laws and practical situations and tried to associate with other parliamentary democracies.
\end{abstract}

\section{Keywords}

Legal Framework, Executive, Accountability, Parliamentary Democracy, Separation of Power, Answerability

\section{Introduction}

The notion of accountability is an amorphous concept that is difficult to define in precise terms. However, broadly speaking, accountability exists when there is a relationship where an individual or body and the performance of tasks or 
functions by the individual or body, are subject to another's oversight, direction or request that they provide information or justification for their actions (Hurst \& O'Brien, 2010). The concept of accountability involves two distinct stages, i.e. answerability and enforcement (Akpanuko \& Asogwa, 2013). Answerability means having to provide information about one's actions and justifications for their correctness. Thus answerability consists of two aspects; explanatory and informational components (Akpanuko \& Asogwa, 2013). Enforcement suggests that the public or the institution responsible for accountability can sanction the offending party or remedy the contravening behavior (Akpanuko \& Asogwa, 2013). As such, different institutions of accountability might be responsible for either or both of these stages.

Working Parliaments and democratic institutions are the locus of accountability in this regard. Since accountability ensures actions and decisions taken by public officials are subject to oversight so as to guarantee that government initiatives meet their stated objectives and respond to the needs of the community they are meant to be benefiting, as a result contributing to better governance (Akpanuko \& Asogwa, 2013).

Evaluating the ongoing effectiveness of public officials or public bodies ensures that they are performing to their full potential, providing value for money in the provision of public services, instilling confidence in the government and being responsive to the community they serve. That is why accountability is important to governance.

The notion of accountability is not likely in the absence of separation of powers. The major institutions of state should be functionally independent and that no individual should have powers that span these offices. The principal institutions are usually taken to be the executive, the legislature and the judiciary (Benwell \& Gay, Last Updated 15, August 2017). Executive accountability functions with such inception of split of power. Initially, separation of power was conceived to protect life and liberty by making it hard for the government to take action by subjecting proposed actions to deliberation and by providing checks on action by one branch by another branch with competing ambitions (Document of Freedom, Accessed on January 2017). The teaching of Montesquieu signifies that justice will jeopardize when the three powers of the government intermingled (Cohen \& Varat, 2012).

According to Daniel A. Farber et al. separation of power means specialization according to relative expertise (Daniel et al., 2017). The legislative body is best at making broad policy choices and so it is structured to include diverse constituencies and to require deliberation. The executive in contrast is structured for quick and decisive action. It also emerges as the chief force for policy integration and coordination. This is especially true during times of war or national emergency. If the executive action is not justified by the authorizations in law and/or is action authorized to the legislator, then it is ultra virus and unconstitutional enforced by the judiciary or the voter (Farber, Eskridge Jr., Frickey, \& Schacter, 2017). 
Separation of power in the modern sense is not to say that the three branches are not co-ordinate parts of one government and that each in the field of its duties may not involve the actions of the two other branches in so far as the action involved shall not be an assumption of the constitutional field of action of another branch. Rather, in determining what it may do in seeking assistance from another branch the extent and character of that assistance must be fixed according to common sense and the inherent necessities of the governmental coordination (Separation of Powers, 2018).

Therefore, separation of power is designed to establish a system of checks and balances to keep any one branch from exercising too much power and it is a system, where the power of one branch can be challenged by another branch.

The executive branch of the government has the sole authority and responsibility for the daily administration of the state bureaucracy. The executive branch is the chief of the state, chief diplomat, commander in chief, chief contributor for the legislative and guardian of the economy (Singh \& Vijay, 2013). So, strong scrutiny of the power of the executive is essential. One approach, adopted by Lord Sharman in his 2001 Report reviewing audit and accountability for central government, divides the notion of accountability into the following four aspects (Sharman, 2001):

1) Giving an explanation: Parliament and other main stake-holders are advised about what is happening, through an annual report, outlining performance and activity;

2) Providing further information: where those accountable may be asked to account further, beyond information already given;

3) Reviewing and revising: where those accountable respond by examining performance, systems or practices, and if necessary, making changes to meet the expectations of stakeholders; and

4) Granting redress or imposing sanctions: if a mechanism to impose sanctions exists, stakeholders might enforce their rights on those accountable to effect changes (Sharman, 2001).

Separation of power in Ethiopia comprises of the executive, legislative and the judicial branches. The executive branch signified by Council of Ministers includes the Prime Minister, Deputy Prime Ministers and other ministers elected by the parliament by the recommendation of the Prime Minister (Ethiopar, 2018). The members of the council of ministers may elected from the members of the parliament and serve the two organs at the same time. There is strong fusion of power between the legislative and the executive. The legislative branch includes the two Chambers of Federal Parliamentary Assembly - the house of People's Representatives and the house of the Federation. The house shall have the power of legislation in all matters assigned by the federal constitution to the federal jurisdiction (FDRE Constitution, 1995, article 54 \& 55). Members of house of federation shall be elected by the state council. This house is a non-law making part of parliament has the power to interpret the constitution (FDRE Constitution, Art. 62). 
Britain, Germany, India and Ethiopia share the same parliamentary system of government. Sharing the same system could not be the only reason to make a synthesis of this article. Britain an oldest parliamentary democracy in the world and best in preserving their tradition is helpful to explore the system for any country. India is a large democracy, diverse, and a developing state is the most conformable example for a country like Ethiopia has to learn. Germany with strong federal structure and strong executive which is lead by the chancellor could be the best case in point for other parliamentary democracies. Exploring the experience of executive accountability in these countries in a comparative manner is helpful for the advance of knowledge and to share worthy experience of these countries. The article articulates the theoretical foundations of parliamentary democracies and it attempts to bring to the Ethiopian case.

\section{Constitutional Synthesis for Executive Accountability}

The two constitutional syntheses most common in the democratic world are parliamentary and presidential models. These two systems are structural opposites with regard to setting out rules for the formation and termination of governments. Parliamentary system that operates in countries such as Germany and Ethiopia is characterized by a fusion of powers and a mutual dependence between the executive (usually a prime minister or chancellor). The power of the prime minister emanates from the legislator after elections and needs the confidence of the legislature in order for his government to survive the duration of the legislator's term (Sketch, 2007). Parliamentary systems foster stronger political parties, more centralized and party-aligned interest groups, a more centralized decision-making process, and more centralized and hierarchical administrative structures (Strom et al., 2009). The system encourages collaboration between the legislature and executive, maintains inter electoral flexibility, and functions as an automatic safety-valve in the case of an unpopular prime minister or government; if the administration loses a vote of confidence or censure in parliament, then by convention they have to resign (Binghamton, 2007).

The Presidential system which is mainly symbolized by America is characterized by the separation of powers and a mutual independence of the executive and legislative powers. In a presidential system, the legislature is far more engaged in its function of scrutinizing, modifying and throwing out executive sponsored legislation (Buisseret, 2017). This is because the chief executive (a popularly elected president) and the legislature are elected independently of each other, for fixed terms of office, and both can survive for their respective terms without the other's approval. Until the early 1990s most democracies fit neatly into one of these two constitutional types (Buisseret, 2017).

Yet, by the mid-1990s numerous emerging democracies which were under communist regime met one of the defining criteria for presidential system while also fulfilling one of the essential criteria for parliamentary system (Vitalino Canas-\&quo, 2004). No purely presidential constitution combines both of these characteristics and the incentive structures they embody, nor does any purely 
parliamentary constitution. Thus at this time there is a third constitutional model which is called semi-presidential system (Vitalino Canas-\&quo, 2004).

The most critical feature of semi-presidential system is the additional split of powers that comes with the division of the executive into two independently legitimized and constitutionally powerful institutions: an indirectly selected head of government (prime minister) and popularly elected head of state (president). Interestingly, executive power in most semi-presidential constitutions, including the power to preside over cabinet meetings and to direct national policy, is shared between these two executives though it precludes a neat division or clear separation of powers often leading to constitutional ambiguity (Martinez, 1999).

Another feature of this newest separation of powers system is unequal legitimacy, accountability and responsibility of these two executives' vis-à-vis citizens and their elected representatives. The prime minister remains responsible to the legislature and dependent on it for support throughout the legislature's term. The president however is popularly elected by the voters for a fixed term, often for longer term than that of the legislature. The president is therefore, autonomous relative to the legislature in that she/he has an independent and popular mandate and can survive without the legislature's approval. As a result the president has substantial powers with regard to decree, veto, and emergency powers (Martinez, 1999).

This synthesis shows that the issue of executive accountability, legitimacy and responsibility are the main diverging lines. Accordingly, in a presidential system, since the president acquires its legitimacy from the general public, she/he along with the executive branch is accountable for the public during the scheduled terms of election. The legislature has no strong hand to dismiss the president from power and the president is not responsible for the legislature, as such. Unless the president or other member of the executive has committed serious offence, the executive is autonomous and is not the subject of impeachment before the legislator. As a result, the presidential system is less fragile and relatively stable when compared with other systems of government (Elgie, 2018).

In a parliamentary system on the other hand, the legitimacy of the executive is acquired from the legislator or indirectly from the public through its representatives, since the prime minister and other ministers are elected from the winning party and appointed by the parliament (Elgie, 2018). Accordingly the executive is accountable for the legislature. The legislature has a strong hand to dismiss the prime minister and the executive as a whole by a principle of vote of no confidence (Elgie, 2018). This implies that to account the executive, the parliamentary model is much better than a presidential system, provided there is a healthy nature of parliaments. As a result, in most of the parliamentary democracies, the government is fragile and less stable as the strong hand of the parliament disperses the executive when it lacks confidence and finds it difficult to form coalition governments (Elgie, 2018).

Semi-presidential system on the other hand reflects aspects of the two systems. While the president acquires its legitimacy from the public, the prime mi- 
nister is elected by the legislator. Their accountability also leads to their voters. As such the president is accountable for the public and the prime minister to the legislature (Shugart, 2005). Most of the time, this system inclines to the presidential system since the president is stronger than the prime minister. This is clearly shown in Frances' semi-presidential system (Shugart, 2005). The strong exercise of power is resided on the shoulder of the president. Since power legitimacy is acquired from the public, the impeachment of the president before the parliament is less frequent than the prime minister. Parliamentary systems are fertile to establish responsive executive.

\subsection{Executive Political Accountability in Britain}

Britain is a unitary state and has a parliamentary system of government. It further has a bicameral legislature (the House of Commons and the House of Lords), the cabinet and a judiciary, which includes the House of Lords as the highest court of appeal. The head of state (i.e. the Monarch) is separated from the head of government (i.e. the prime minister) and the former performs largely ceremonial functions. The prime minister leads a cabinet consisting of members of the legislature. The Prime Minister answers questions every Wednesday (De Dios, 2012). The leader of the opposition is permitted to put three or four supplementaires in succession and the leader of the next largest opposition party is allowed two (De Dios, 2012). The debate is always related to the PM's responsibilities or to almost any aspect of government policy, logically is about highly topical matters (De Dios, 2012). The executive who includes the monarch, prime minister, and the cabinet is under the parliamentary sovereignty (De Dios, 2012).

In Britain ministers who compose the executive branch are accountable to the parliament and through the parliament to the public. Ministers have both collective responsibility for government policy and individual responsibility for their own departments work.

According to ministerial code /1997/ of Britain, ministers are expected; to uphold the principles of the collective responsibility. They have a duty to parliament to account and be held to account for the policies, decisions and actions of their department and next steps agencies. Most of the oversight is done through 30 parliamentary committees, among which the house's public accounts committee is chaired by a member of the opposition (Assefa, 2010).

Ministers are duty bound to give accurate and truthful information to parliament, correcting any inadvertent error at the earliest opportunity. Ministers knowingly mislead parliament will be expected to offer their resignation to the prime minister. They should be as open as possible with parliament and the public save the public interest (Assefa, 2010).

The House of Commons have a vital role in scrutinizing the work of the government through various mechanisms, including questioning ministers in the chamber and through select committee system. It has a power to force the government to resign. Following a defeat on an important issue in the House of 
Commons the government is obliged to resign or seen a dissolution. But the practice shows that a defeat on confident motion is the only motion to resign or dissolve (Executive Accountability, accessed on January 2017).

\subsection{Executive Political Accountability in Germany}

Germany is a federal parliamentary democracy governed under the Basic Law for the Federal Republic of Germany ("Basic Law"), the Constitution of Germany (Fact Sheet, 2015). With a federal republic and a parliamentary system of government, Germany has a bicameral legislature (the Bundestag and Bundesrat), the executive and a judiciary which includes a constitutional court. The head of state is the federal president, who is separated from the head of government (the federal chancellor). The federal chancellor, who is elected by the Bundestag, leads a cabinet consisting of federal ministers. Neither the federal chancellor nor the federal ministers are required to be members of the legislature. The Bundestag is usually referred as federal parliament, while the Budesrat as the federal council (Fact Sheet, 2015).

The president is elected by the federal convention, a constitutional body which convenes for this purpose. The Bundestag or the Bundesrat may impeach the federal president before the federal constitutional court for willful violation of the basic law or any other federal law (Fact Sheet, 2015).

The chancellor is the chairman of the cabinet and head of government. The chancellor is nominated by the president and elected without debate by the bundestag. The Bundestag may express its lack of confidence in the chancellor only by electing a successor with a majority vote of its members known as "constructive vote of confidence" (Venter, 2014). The chancellor determines and is responsible for the general policy guidelines. The chancellor is accountable to the parliament. Only the chancellor can propose a vote of confidence (which is different from the constructive vote of confidence mentioned above) and request the dissolution of the Bundestag (Venter, 2014).

In Germany, the opposition and various special committees supported by experts from the civil service may arrange discussions regarding the conduct of the executive and establish a committee of inquiry or order to undertake investigation (Assefa, 2010). The Bundestag, the role of scrutinizing the government is naturally performed first and foremost by the opposition groups, although Members from the groups in the governing coalition engage in scrutiny too through their participation in parliamentary processes (The Secretary-General, 2013).

The chancellor has the power to name members of the cabinet and can create or abolish federal ministerial departments. Cabinet ministers are appointed and dismissed by the president upon the proposal of the chancellor. Federal ministers conduct and are responsible for the business of their own departments to the chancellor. Collective responsibility is not well developed in general and channels for the cabinet to be accountable to parliament are limited (Executive 
Accountability, Accessed on January 2017).

\subsection{Executive Political Accountability in India}

The Constitution of India provides for a parliament consisting of an elected president and the two houses, the House of the People, (Lok Sabha) and the Council of States (Rajya Sabha) (Constitution of India, 2015). Like other parliamentary systems, the parliament serves as a locus of accountability and oversight. India's parliament has various accountability mechanisms at its disposal. The lower house Lok Sabha has several committee systems that are either ad hoc or standing (Assefa, 2010). Like Britain the public's accounts committee is chaired by the opposition member. Most of Lok Sabha committees are joint committees of Rajya Sabha, the upper house. These committees review activities carried out by different governmental departments (Assefa, 2010).

Indian parliament has executive check mechanisms like no confidence motion, large composition of the opposition and other assurance and accountability mechanisms (Kapur \& Mehta, 2006). The parliament can introduce a motion of no confidence in the government which if sustained, would result in the fall of the government. But the effectiveness of no confidence motions as a discipline device depends upon the alternative available to replace a sitting government. No confidence motions can be successful only in a very limited scenario where governments have a small majority, and a small part of the majority has some reasons to defect to another coalition or seek a general election that would result in the dissolution of government (Kashyap, 1988).

The opposition is the constituent part of parliament which uses statutory process of parliament as a tool to keep the government accountable. If the government has relatively fewer seats and the opposition has bargaining resources, then policy making could be shaped by the opposition (Kashyap, 1988). Parliamentary committees provide a more vigilant locus of accountability if the members of the opposition involve in such committees. Members of the legislature may be reluctant to call to account a government that is made up of leaders of their party.

Opposition day is another contributing factor for proper accountability mechanism in India. In this day opposition parties have the freedom to choose matters they want to table and have them debated (Assefa, 2010). This is the best arrangement to expose the malpractices of the governor party and to have a debate on that (Assefa, 2010).

\subsection{Political Executive Accountability in Ethiopia}

\subsubsection{Political Executive Accountability in FDRE Constitution}

The 1995 Ethiopian constitution is forerunner in many aspects in the history of the country. This is the first constitution in Ethiopia which declares the Federal Democratic Republic of Ethiopia (FDRE Constitution, 1995, Article 1). So doing, power is shared among the federal government and regional states which com- 
prises nine self-governing states and two city administrations. The republican system of governance is enshrined under the federal and regional states constitutions. Accordingly the three wings of government at the federal and state level are established. The fundamental rights and freedoms stated under Chapter Three of the Constitution and the constitutional principles expressed under article 8 up to 12 show the commitment of the government to the democratization process.

These basic provisions of the Constitution signify that the new regime that came in 1991 show willingness to set up the democratic system of governance and accommodation of diversity. The constitution has declared this system under article 45. The check and balance systems among the three wings of the government and accountability and transparency principles also enshrined under different provisions of FDRE Constitution (FDRE Constitution, 1995, Article 12, 53, 72 and 78).

The Constitution declares its supremacy and imposes an obligation on all citizens, organs of state, political organizations and other associations to observe and enforce the constitutional system (FDRE Constitution, 1995, Article 9 (2)). Besides any law, customary practice or a decision of an organ of a state or a public official which contravenes this Constitution shall be of no effect (FDRE Constitution, 1995, Article 9). This is the first provision in sequence within the constitution which deals about accountability.

The firm principle regarding accountability is declared under article 12 of the Constitution. Any public official or an elected representative is accountable for any failure in official duties. In case of loss of confidence, the people may recall an elected representative. This is the general accountability clause applied to executive branch of the government (FDRE Constitution, 1995, Article 12).

Another relevant provision regarding the accountability of the government declares that "The conduct of affairs of government shall be transparent (article 12 of the constitution). Reinforcing this article 29 (3) provides for access to information of public interest. This facilitates the accountability of government organs through exposing the malpractices to the public and the concerned bodies and forcing to rectify it.

Like other parliamentary systems, the Federal parliament of Ethiopia is a locus of accountability. Accordingly, the house of people's representatives has extensive powers with regard to accounting the executive. Art. 55 (7) of the Constitution empower the House to determine the organization of national defense, public security and a national police force (FDRE Constitution, 1995). The House shall carry out investigations and take necessary measures, if the conduct of these forces infringes upon human rights and the nation's security. The measure is extended to take constructive and punitive measures through the chief executive (Getachew Assefa, 2008).

Among the excessive powers of the executive, declaring the state of emergency is the key one. Scrutinizing the executive is much necessitated in this regard. The Constitution under Article 55/8/ empowers the House to consider and resolve 
on a decree of a state of emergency declared by the executive (FDRE Constitution, 1995, Article 5 5(8)). The state of emergency decreed by the Council of Ministers must be submitted to the House within 48 hours. The decree, if not approved by a two-thirds majority vote of members shall be repealed forthwith (FDRE Constitution, 1995, Article 93(2) (a)). If it is approved, the House shall simultaneously establish a State of Emergency Inquiry Board, comprising of seven persons to be chosen and assigned by the House from among its members and from legal experts (FDRE Constitution, 1995, 1995 Article 93(5)). The Board is required to inspect and follow up that no measure taken during the state of emergency is inhumane (FDRE Constitution, 1995, Article 93(6) (b)). However, the Constitution is silent regarding the measure to be taken against the executive in case it transgresses the prohibitions.

Ratification of International agreements concluded by the executive and the appointment of federal judges, members of the council of ministers, commissioners, the Auditor General, and of other officials whose appointment is required by law to be approved by the parliament pursuant to (FDRE Constitution, 1995, Art 55/12/ \& /13/). This oversight is designed to restrain the executive and to halt corruption and related crimes.

Article 55/17/ entitles the House to call and to question the Prime Minister and other federal officials and to investigate the executives conduct and discharge of its responsibilities (FDRE Constitution, 1995). It includes the power to order the Prime Minister to take punitive and constructive measures against the officials who commit fault (FDRE Constitution, 1995, Article 55 (17) \& 74 (8)). The parliament has also the mandate at the request of one third of its members; to discuss any matter pertaining to the powers of the executive. It has in such cases, the power to take decisions or measures it deems necessary (FDRE Constitution, 1995, Article 55 (18).

Like Germany and India the parliament of Ethiopia is duty bound to establish standing and ad hoc committees as it deems necessary to accomplish its functions. Currently the house has about 18 standing committees (House of Peoples Representatives, 2017). Among these, the Government Finance and Procurement Standing Committee are chaired by the opposition member. These committees have the duty to oversight government agencies as to whether the latter accomplished their tasks as specified under their annual budget (Assefa, 2010).

The Prime Minister and the Council of Ministers are responsible to the House of People's Representatives. In the exercise of state functions, members of the Council of Ministers are collectively responsible for all decisions they make as a body. The House will question the executive including the Prime Minister as to their conduct collectively or individually (FDRE Constitution, 1995, Article 72 \& 76). More over the Prime Minister shall submit to the House of People's Representatives periodic reports on work accomplished by the executive as well as on its plans and proposals (FDRE Constitution, 1995, Article, 74 (11)).

At last Art 101/2/ provides that the Auditor General shall audit and inspect the accounts of ministers and other agencies of the federal government to ensure 
that expenditures are properly made for activities carried out during the fiscal year and in accordance with the approved allocations and submit his reports there on to the House of Peoples Representatives. The Auditor General in its 2010 (The Auditor General Report, 2011) and the following budget years report exposed many governmental agencies weakness to use their budget and extravagant spending.

\subsubsection{Political Executive Accountability under Subsidiary Laws}

In addition to the grand law of the country, different proclamations and regulations issued by the Parliament and the Council of Ministers respectively pinpointed the accountability mechanisms of the executive. Among these, "A Proclamation to Provide for the Definition of Powers and Duties of the Executive Organs of the Federal Democratic Republic of Ethiopia (Proclamation No. 916, 2015)" declares that Each Ministry shall have the powers and duties to direct and coordinate the performances of the executive organs made accountable to it under the laws establishing them or under Article 33 of the Proclamation; review the organizational structures as well as the work programs and budgets of the executive organs and approve their submission to the appropriate government organs (Proclamation No. 916, 2010, Article 10 (2)). The Proclamation authorizes the ministers to direct and coordinate the executive organs under them. It is also be shouldered to submit periodical reports to the appropriate organs of the government i.e. to the chief executive, council of ministers and the parliament.

Article 11 of this proclamation declares the accountability and responsibility of ministers.

Accordingly, each minister shall be accountable to the prime minister and the council of ministers (Proclamation No. 916, 2010, Article 11). Political considerations are important in the hiring and firing of ministers, but, in democracies, these embrace public opinion (Fischer, Dowding, \& Dumont, 2012). Article $12 / 1$ / each minister of state or vice minister of a ministry shall be accountable to the minister and shall carry out the responsibilities specifically entrusted to him. There are also other federal executive organs which are directly accountable to the prime minister as provided under article 33 of the proclamation. These provisions deal with the accountability mechanisms within the executive or it is the self checking mechanism devised in the executive branch.

Another significant legislation which reinforces the accountability of the executive is council of ministers function directive. The directive declares the responsibility of the council of ministers. Accordingly, the council of ministers is accountable to the Prime Minister and in its decisions it is accountable to the House of People's Representatives pursuant to article 2. In addition to this, ministers have individual responsibility and accountability with regard to their specific duty and as a member of the Council of Ministers; thus a minister will have collective responsibility and accountability (Council of Ministers, 1996).

Concerning impeachment of ministers the Directive has provided that as soon 
as a minister has received summons of an impeachment, he has to inform the Prime Minister and the latter must inform the Council as per article 8/2/ of the directive. If the accusation of the minister is related with the powers and duties of the ministry, the Council of Ministers will assign the Ministry of Justice to follow up the case, but if it is out of his professional responsibility, the minister is responsible for any risk he incurred (Council of Ministers, 1996).

Supervision and follow up is another tool of the parliament to check the executive. In relation to problems it realized during the process of conducting follow up and supervision of government bodies, the House may take the remedial measures. It shall take corrective measures; cause a given governmental office to recognize its problem and give it directives to correct its weakness. Where the problem is not rectified and where it is serious, it shall cause a measure to be taken through the Prime Minster on the body responsible for the problem, and shall follow up the implementation of the measure taken (HPR Rules of Procedure, 1998).

The legal frameworks promulgated by the Parliament and the Council of $\mathrm{Mi}$ nisters to ensure the accountability of the executive have a role in safeguarding democratization. The above laws and organs of state facilitate not only legal accountability but also political accountability through providing ample evidence through report to the Parliament since they are accountable to the House.

\section{Creating a Nexus}

The above discussion shows that these parliamentary democracies have unique attributes for others to learn. In Britain which is not the case in Ethiopia, the Prime Minister's question time commenced every Wednesday has created a forum for the opposition to raise topical issues and to check the executive. Misters have both collective responsibility for government policy and individual responsibility for their own departments work. Collective responsibility is not the case in Germany, India and Ethiopia. House of commons has a power to force the government to resign unless each minister who intentionally misled the house gives their resignation to the prime minister voluntarily. It can arrange no confident motion against executive. Like House of Commons, the Bundestag in Germany may express its lack of confidence against the chancellor. But it is possible only by electing a successor with a majority vote of its members known as "constructive vote of confidence." Neither the federal chancellor nor the federal ministers are required to be a member of the legislature in Germany the opposite is true in Ethiopia. This is special arrangement uncommon to parliamentary systems which circumvent fusion of power. The Bundestag or the Bundesrat may impeach the federal president before the federal constitutional court for willful violation of the basic law or any other federal law what Ethiopian laws didn't mention about impeachment. The Bundestag, the role of scrutinizing the government is naturally performed first and foremost by the opposition groups. In India Most of Lok Sabha committees are joint committees of Rajya Sabha and 
committees review activities carried out by different governmental departments. This is a special arrangement unusual to other parliamentary systems. In the opposition day opposition parties have the freedom to choose matters they want to table and have them debated. This enables them to address sensitive issues of the country and instill opposition ideas.

Existence of ad hoc and standing committees, the proper composition of the house with the opposition and other special arrangements like opposition day, vote of no confidence and truth finding methods have substantial role in developed nations. Ethiopia has also put some of these systems in place. The ad hoc and standing committees, the opposition parties and truth finding mechanisms are recognized at the Constitution and other legislations. Committees have great role in accounting the executive in the Ethiopian case also. Reports are the hearing mechanisms to this sake. Government agencies are duty bound to submit reports and budget plans to the standing committees and thereby to the House. The report shall be quarterly report for the standing committees and annual report to the house. Human Right Commission, Ombudsman, General Auditor, Supreme Court and other similar institutions are duty bound to report to the standing committee and sometimes to the house at least once a year ${ }^{1}$. Reports can be either plan report at the start of the year or performance report which may be quarterly or annually. The member of the committee and the house shall contest the reports and give directions as to their enabling act to be corrected. As to the conditions, the committee may collect public questions and opinions to challenge institutions and reporting ministers. In addition to reports, committees may devise field visits. Through the field visit they directly observe the performance of great projects, public grievances and other public issues.

Calling and questioning the prime minister and other ministers as the situation require (every Wednesday in Britain) is another weapon to the parliament to check the executive. If the house assume that situations show that the chief executive or his subordinates be called and questioned, it shall arrange such arrangements and investigate the fact. As to its finding the house may order the situations to be rectified and to be taken constructive and punitive measures by the chief executive. To do so an alert and effective opposition is as much necessary as a majority ruling party in a parliamentary system (Tiwana, 1994).

Though committees play great role in every actions of the house, there are also challenges to end their missions. Scarcity of budget, technologies, expertise and absence of opposition parties' participation has barred them not to use their full potential. Especially in case the participation of the opposition parties is nil like the present parliament, the system requires strong committees which are partisan to the public and the constitution rather than sticking to party discipline.

${ }^{1}$ The data was collected from the Federal House of People Representatives Anonyms informants. Key informants are selected from the legal and administrative standing committee randomly and the deputy chair person is selected as to his merit, since he is a member of the house and the standing committee for about 10 years (elected for two terms) in addition to his qualification graduate of law from Addis Ababa University. 
When members of the house give precedence to party loyalty, checking the executive branch is difficult. But members of the standing committees which were subject to this finding objected this idea, since they believe that the policy of the party is strictly depending on the public interest and according to the constitution; and then sticking to party discipline means sticking to the countries interest at large. Therefore "always we stick to public interest since the party discipline is in line with the countries interest" 2

In modern state which is led by popular sovereignty checking the executive primarily benefits the executive itself. Thus devising strong accounting system is the desire of the general public and indispensable to the democratization of the country whoever the composition of the house is. But the experience of developed countries show that, when the composition of the house diversified with different political ideologies the democratization process will speed up and the executive will be delicate to each and every decisions. Therefore the writer is in good turn of the developed countries which promote the multi-party system and diversity of ideas.

The Ethiopian parliament contrary to the above parliamentary states, the house has no power to impeach, dismiss or to ensue vote of no confidence directly to the executive. There is strong fusion of power among the executive and the parliament (which is not the case in Germany). The decisions of the house towards the executive are only possible through government answerable minster to the parliament. The government answerable minister in the parliament proceeds to enforce the directions of the house to take corrective measures. The decisions of the house are left in the whim of the executive. The power to the house is limited to giving directions to the chief executive to take constructive or punitive measures against the body which commit fault. These are the loop holes of Ethiopian political executive accountability when equated with parliamentary systems like Germany, India and Britain.

The working parliament, not the fusion of majority party and government but the institutional composite between legislature and executive characterizes the system and thereby the legislature (Monnet, 2002).

\section{Conclusions}

Ethiopia, starting from 1995 has promulgated different legislations focused on different spheres. As it is an infant and emerging legal system, it is rung with different hindrances. Ethiopia has to learn from Britain concerning checking the Prime Minister, involvement of the opposition parties and individual and collective responsibility. Germany is the best example Ethiopia has to learn through devising the mechanism to avoid fusion of power between the parliament and the executive. India has an "opposition day" a best forum for parties to raise topical issues and to discuss. Joint committees of the two Houses are another contribution of India's Parliamentary democracy. Vote of no confidence motion 
against the executive is the case in the above parliamentary democracies which must be instill in Ethiopian parliament (Greater Executive Accountability, 2007).

Legislatures should be well equipped with expert assistance on technical matters and with continuous training. Strong committee system and develop sense of loyalty and pride to parliamentary institutions ensures the accountability tradition. Over sight based on policies and not just politics will help to create efficient government. Capacity building at individual and institutional level and active civil society organization and media supports, an autonomous status of parliament in terms of budget and service, detailed discussions on policies and laws, more sittings and more time to debate on the budget, the enactment of law, reports of committees and issues relating to urgent public importance and welfare of people.

\section{Conflicts of Interest}

The author declares no conflicts of interest regarding the publication of this paper.

\section{References}

Akpanuko, E. E., \& Asogwa, I. E. (2013). Accountability: A Synthesis. International Journal of Finance and Accounting, 2, 164-173.

Assefa, G. (2010). Ensuring Constitutionalism through Parliamentary Oversight, Constitutional Law Series 3 (p. 170). Addis Ababa University Press.

Benwell, R., \& Gay, O. (2017). The Separation of Powers. Parliament and Constitution Centre.

https://www.google.com/url?sa=t\&rct=j\&q=\&esrc=s\&source=web\&cd=1\&ved=0ahUK Ewi5k_aSs_7VAhUBmxQKHcHcCYQQFgglMAA\&url=http\%3A\%2F\%2Fresearchbrief ings.files.parliament.uk\%2Fdocuments\%2FSN06053\%2FSN06053.pdf\&usg=AFQjCNG pDZPe2cIAiXI5kKTQ790CCCPtMQ

Binghamton (2007) Presidential and Parliamentary Executives, Driving Democracy-Chapter 6 (p. 8). Binghamton, NY: Banner Software, Inc.

Buisseret, P. (2017). Parliamentary or Presidential Government (p. 7)? Princeton, NJ: Princeton University.

https://www.princeton.edu/politics/about/filerepository/public/Buisseret-Pres-or-Parl. pdf

Constitution of India (2015) Published by Government of India Ministry of Law and Justice (Legislative Department). Article 69.

http://legislative.gov.in/sites/default/files/coi-4March2016.pdf

Council of Ministers Function Directive (1996). Addis Ababa.

Farber, D., Eskridge Jr., W., Frickey, P., \& Schacter, J. (2017). Constitutional Law Themes for the Constitutions (4th ed., pp. 134-135). American Case Book Series, West Publishing Co.

De Dios, M. S. (2012). The Accountability Game in Parliamentary Democracy (p. 4). Madrid: Universidad Complutense de Madrid.

Definition of Powers and Duties of the Executive Organs of the Federal Democratic Republic of Ethiopia Proclamation (2015) No. 916/2015, Article 10(2). 
Documents of Freedom: History, Government and Economics through Primary Sources. Separation of Powers with Checks and Balances. https://www.docsoffreedom.org/

Elgie, R. (2018). The Politics of Semi Presidentialism.

https://scholar.google.com/scholar?q=Robert+Elgie,+The+Politics+of+semi+Presidenti al-

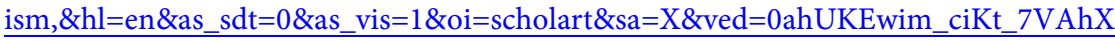
LKlAKHe2RBWsQgQMIIzAA

Ethiopar: A 3rd Party Informational Website and Is in No Way Affiliated with Any Branch of the Government of Ethiopia, 2018. http://www.ethiopar.net/government

Executive Accountability System in the United Kingdom, Germany, France and Hong Kong, Research and Library Services Division, Legislative Council Secretariat (p. 2). http://www.legco.gov.hk/yr00-01/english/library/0001in14.pdf

Fact Sheet (2015). Political System of Germany, Research Office, Legislative Council Secretariat (p. 1).

http://www.legco.gov.hk/research-publications/english/1415fsc05-political-system-of-g ermany-20150218-e.pdf

Federal Democratic Republic of Ethiopia Constitution (1995). First Edition No. 1, Addis Ababa Article 1.

Federal Democratic Republic of Ethiopia House of Peoples Representatives Website. http://www.ethiopia.gov.et/the-house-of-peoples-representatives

Fischer, J., Dowding, K., \& Dumont, P. (2012). The Duration and Durability of Cabinet Ministers. International Political Science Review, 33, 505-519. http://www.jstor.org/stable/23353156

Hurst, R. S., \& O'Brien, M. (2010). The Note on Accountability in Governance and Its Sub Sections. Washington DC: World Bank Institute, Social Accountability in the Public Sector.

Kapur, D., \& Mehta (2006) The Indian Parliament as an Institution of Accountability. 1.

Kashyap, S. C. (1988). Parliament of India: Myths and Realities (pp. 35, 39-43). New Delhi: National Publishing House.

Martinez, R. (1999). Semi-Presidentialism: A Comparative Study. ECPR Joint Sessions Mannheim, 26-31 Workshop No 13: Universitat de Barcelona. https://ecpr.eu/Filestore/PaperProposal/f518abfd-8657-489e-9a3b-a7a89850aa4d.pdf

Separation of Powers (2018). An Overview. National Conference of State Legislators. http://www.ncsl.org/research/about-state-legislatures/separation-of-powers-an-overvie w.aspx

Sharman, L. (2001). Holding the Executive to Account: The Review of Audit and Accountability for Central Government.

Shugart, M. S. (2005). Semi-Presidential Systems: Dual Executive and Mixed Authority Patterns. London: Palgrave Macmillan Ltd. http://www.palgrave-journals.com/fp

Singh, N., \& Vijay, A. (2013). Separation of Powers: Constitutional Plan and Practice. International Journal of Scientific and Research Publications, 3, 1-6.

Sketch, C. (2007) The Newest Separation of Powers: Semi Presidential. International Journal of Constitutional Law, Volume 5, 95-97.

https://doi.org/10.1093/icon/mol025

Strom, J. G., Thacker, C., \& Moreno, C. (2009). Are Parliamentary Systems Better (p. 5)? Boston, MA: Boston University.

The Auditor General Report (2011). To the Ethiopian Parliament. 
The House of Peoples Representatives (HPR) of the Federal Democratic Republic of Ethiopia Rules of Procedures and Members (1998). Code of Conduct Regulation No. 3, Article 75(6).

The Need for Reforms to Secure Greater Executive Accountability 53rd Common Wealth Parliamentary Conference (2007). New Delhi, India.

The Secretary-General (2013). Parliamentary Democracy in Action (p. 15).

Tiwana, S. S. (1994). Crisis in Indian Parliamentary Democracy. The Indian Journal of Political Science, 55, 55-62. http://www.jstor.org/stable/41855680

Venter, R. (2014). Motions of No Confidence and the Separation of Powers: A Comparative Perspective. Johannesburg: University of Johannesburg.

https://www.jus.uio.no/english/research/news-and-events/events/conferences/2014/wc cl-cmdc/wccl/papers/ws15/w15-venter.pdf

Vitalino Canas-\&quo (2004). The Semi-Presidential System, Max-Planck-Institut für ausländisches öffentliches Recht und Völkerrecht. http://www.zaoerv.de 